\title{
Benefits Derived by District Assemblies from Their Project Consultants
}

\author{
Joshua Ayarkwa $^{1}$, B. K. Baiden ${ }^{1} \&$ D. Osei-Asibey ${ }^{1}$ \\ ${ }^{1}$ Department of Building Technology, Kwame Nkrumah University of Science and Technology, Kumasi, Ghana \\ Correspondence: Joshua Ayarkwa, Department of Building Technology, Kwame Nkrumah University of Science \\ and Technology, Kumasi, Ghana. Tel: 233-246-010-870. E-mail: ayarkwajosh@yahoo.com
}

Received: May 29, 2013 Accepted: July 6, 2013 Online Published: September 4, 2013

doi:10.5539/emr.v2n2p41 URL: http://dx.doi.org/10.5539/emr.v2n2p41

\begin{abstract}
Many of the problems in construction at the local authority level can be traced to consultants who supervise projects on behalf of local government agencies. Consultants therefore need to be evaluated regularly to ensure that they are delivering the expected benefits to their clients. This study seeks to assess the benefits District Assemblies (DAs) in Ghana derive from their consultants who supervise projects funded through the District Assemblies' Common Fund. The study involved a postal survey of 80 DAs and identified the expected benefits the DAs would like to attain through the services of their consultants and the perceived actual benefits they had received. The study then highlights the weaknesses of the consultants for corresponding adjustments to satisfy the expectations of their clients. The one-way analysis of variance (ANOVA) $(p=0.05)$ was used to determine the significance of the differences between the expected and the actual benefits. The findings revealed that, of the documented benefits DAs would expect to receive from the professional services rendered by their consultants, increasing accuracy of project budget estimation, saving cost, minimizing risk through improved tender documents, promoting better communication with clients, and meeting clients' deadline were considered important benefits by the DAs. There were significant differences between the expected benefits and the level of benefits achieved from consultants. The actual benefits were generally lower than that expected by the DAs. District Assemblies' consultants need to improve their ability to help enhance organization's quality image, improve quality of engineering study recommendation and increase accuracy of project budget estimation among others, in order to meet their clients' satisfaction. The paper is of value to local government agencies wishing to obtain greater benefits from their project consultants, and consultants wishing to realize their weaknesses for continual improvement.
\end{abstract}

Keywords: district assemblies, consultants, benefits, Ghana

\section{Introduction}

The concept of Local Governance in Ghana dates back to 1850s when the Colonial Government issued the Municipal Ordinance to cover Cape Coast and its environs (Osei-Asibey, 2005). This centralized system of governance continued until the introduction of the Local Government Act (ACT 54) in 1961 which was expected to fully decentralize governance in Ghana, but was not implemented. The implementation of decentralized governance was achieved in Ghana in 1988 when the Provisional National Defense Council (PNDC) Law 207 was passed. This law was further strengthened by the Local Government Act, 1993 (ACT 462) which established the District Assemblies (DAs) in the Fourth Republic of Ghana repealing previous laws (Botchway, 2000).

As of June 2011, there were 170 Metropolitan, Municipal and District Assemblies across Ghana. Section 162 of Act 462, defined "District Assemblies" to include Municipal and Metropolitan Assemblies whiles "District Chief Executives" included Metropolitan and Municipal Chief Executives. This study adopts this definition of District Assemblies to include Metropolitan and Municipal Assemblies.

The 1992 Constitution of the Republic of Ghana provides in article 242 that a DA shall consist of one person elected from each local government electoral area within the district, the member or members of parliament for the constituencies that fall within the area of authority of the DA, the District Chief Executive of the District and other members not more than thirty percent of all the members of the DA appointed by the President. 
District Assemblies are composed of at least 11 decentralized departments which include Education, Youth and Sports Department; Social Welfare and Community Development Department, Works Department, Physical Planning Department, Finance Department, Natural Resource Conservation Department, Central Administration, Trade and Industry, Disaster Prevention Department, Health Department and Department of Agriculture (Osei-Asibey, 2005).

The DA is the highest political and administrative body in the district with legislative and executive functions. Section 10 of Act 462 (1993) lists functions of the District Assemblies to include the following:

- To initiate programme for the development of basic infrastructure and provide municipal works and service in the district;

- To promote and encourage other persons or bodies to undertake projects under approved development plans and;

- To monitor the execution of projects under approved development plans and assess and evaluate their impact on the people's development in the local, district and national economy.

In line with the DA's mandate of developing its area, projects are identified or proposed by the DA, local communities or government. Projects are either executed by the Works Department of the DAs or by agents of the DAs (contractors and consultants) depending on the size, cost, duration of the project, manpower and skill required (Botchway, 2000).

The District Assemblies' Common Fund (DACF) was created by Section 252 of the 1992 Constitution of Ghana. The DACF Act, (ACT 455) was enacted in 1993 to allocate not less than 5\% of the total revenue of the nation to the DAs for development (Osei-Asibey, 2005). The DACF is the most important source of funding for DAs and covers between $80-90 \%$ of a DA's annual expenditure (Banful, 2009). Currently, the percentage of the total government revenue to be allocated to the DAs is $7.5 \%$. While there are broad regulatory guidelines, DAs are free to use the funds as they wish if the intended use is in their budgets furnished to the DACF Administrator prior to disbursements (Banful, 2009). District Assemblies (DAs) in Ghana initiate and execute programmes and projects for the development of basic infrastructure in their respective local government jurisdiction. The DACF has provided finance for development in health and sanitation, education, potable water, residential and office accommodation, rehabilitation of roads and provision of community center facilities (Osei-Asibey, 2005). The fund, according to a World Bank report (2004) on the DACF, has become a suitable mechanism for providing resources to the Districts for the provision of basic infrastructure in education, health and water which hitherto have been neglected. However, erratic payment by government and large number of competing needs have put a lot of pressure on the Common Fund. Additionally, the near absence of technically competent and experienced staff in the district, utilization and management of Common Fund projects has been beset with problems (Osei-Asibey, 2005). The DAs often lack the capacity to supervise their development projects, and rely significantly on external consultants. To ensure continued delivery on their roles to the benefit of their clients, the external consultants would require regular evaluation.

\section{Literature Review}

The Public Procurement Act of Ghana, 2003 (Act 663) defines “consultancy services" as services which are of an intellectual and advisory nature provided by firms or individuals using their professional skills to study, design and organize specific projects, advise clients, conduct training or transfer knowledge (Public Procurement Board-Ghana, 2003). In the opinion of Samson and Parker (1994), service work exists because it can outperform the client in meeting their own needs or because clients are incapable of meeting their needs. Act 663 provides that a "consultant" means a person, natural or corporate, dealing in the provision of consultancy services. Consultants have been in the construction sector for a long time. The technical and contractual intricacies of today's infrastructure and construction projects and regulations of some nations necessitate the appointment of project consultants to preserve the rights and interests of the client (Chow \& $\mathrm{Ng}$, 2007), hence the increasing trend of use of consultants to supervise projects on behalf of clients. Consultants are key stakeholders whose actions and inactions have appreciable impacts on projects in the industry, and are accountable for the technical risks in a conventional project (Havemann, 2007). They are responsible for developing the requirements of project clients, setting targets, deadlines and establishing standards for meeting these requirements, preparing project documents that describe the targets etc. While the accuracy and relevance of the consultant's design and recommendations could have profound impacts on the subsequent work quality and claims, evidences reveal that lax control during the construction stage and poor contract administration could also lead to dissatisfaction and project failure (Chini \& Valdez, 2003; Tan \& Lu, 1995; Kasma, 1987). It suffices to say that a project cannot be successfully executed without the services of consultants. Consultants serve to uphold the interests of their client 
and prospective users throughout the whole project cycle (Chow \& $\mathrm{Ng}$, 2007). If an appropriate consultant is selected, chances of delivering a project on time and within budget increases (Federation Internationale Des IngenieursConseils, FIDIC, 1997). In the construction sector, different types of professionals provide advisory services to help achieve the clients' goal. These professionals, depending on the procurement process adopted by the client for the project execution, may be employed directly by the client in his organization or as external consultants, depending on the size and complexity of the project, the clients' organization and the national policy regulation (Chow \& Ng, 2007). For a typical construction process, the services of Architects, Quantity Surveyors, Structural Engineers, Services Engineers, Mechanical and Electrical Engineers may be required.

The quality of service delivered by consultants has seldom been a subject of thorough investigation because some clients have underestimated the impact of substandard consultancy service on the success of construction projects (Barber et al., 2000; Hattan \& Lalani, 1997; Samson \& Parker, 1994). Evaluation of consultants is a means of ensuring that they deliver quality service to the expectation and satisfaction of their clients. As the business environment becomes more and more competitive, the success of a consultant will depend on whether the quality of professional service to preserve the interest of their clients at different stages of a project is satisfactory (Ng, 2005). The introduction of ISO 9000: 2000 places an unprecedented emphasis on customer satisfaction and continual improvement (Goetsch \& Davis, 2002; Murphy, 2002). In the opinion of Hill et al. (2002), "satisfaction" can be measured by comparing the difference between what is expected and actually received, and clients would be satisfied with the performance of a consultant if the quality of service received exceeds or at least meets their expectation. The client should be the arbitrator of what the use is and, subsequently, the fitness (Samson \& Parker, 1994). The client would determine what aspects of the service are most beneficial rather than the consultant dictating these aspects (Samson \& Parker, 1994). A consulting service may also be considered successful if the consultant is satisfied that his or her reputation has been enhanced, with expectations of future revenue streams (McLachlin, 2000). Continual improvement can also be realized if consultants are aware of their deficiencies and make corresponding adjustments to satisfy the expectation of their clients (Love et al., 1998; Flood, 1993). Although organizations use consultants to help accomplish significant goals, such as facilitating organization change, consultants rarely have opportunity to learn how their contributions are perceived by various stakeholders, particularly when they are not invited back for more work (Smith, 2002). The literature suggests numerous factors for consulting engagement success (Bingham, 1992; Covin \& Fisher, 1991). However, most material is descriptive and based on industry experience (Smith, 2002). Few systematic studies have addressed the conditions for successful consulting (Hamilton, 1988; Rynning, 1992). A lot of studies confirm the importance of the consultant's services engaged by companies in order to introduce ISO 9000 quality management systems, but the actual influence of these services has not been fully analyzed (Casadesus et al., 2002). In the opinion of Casadesus et al. (2002), the obvious question is: Has the consultant's services proved beneficial? Are clients satisfied with the services rended by consultants? Have consultants lived up to the expectation of their clients? These questions are obviosly of interest to the clients involved and to consultants eager to determine the degree of client satisfaction, on which their very future depends. The analysis of these questions is even more relevant in the present situation where companies are involved in the process of adaptation to the new ISO 9000:2000 standards. Due to the paucity of information on the benefits derived by clients, particularly those at the local government level, from their external clients, this paper identifies the benefits that DAs in Ghana would expect from their project consultants and compares with the actual benefits they had gained. The results provide the much needed feedback for the consultants to examine their deficiencies for continual improvement and guaranteed benefits to the DAs.

\section{Research Methodology}

At the time of the study, there were 170 Metropolitan, Municipal and District Assemblies in Ghana (www.ghanaweb.com). A sample size of 80 DAs from the total population of 170 DAs, representing 47\%, was selected for the study. According to Bartlett et al. (2001), the minimum sample size for a population of 200 is 74 , indicating the adequacy of the sample size of 80 for the study. Regions of Ghana were considered as strata from which District Assemblies were selected. This was done to ensure that views of DAs from all ten regions of Ghana were included in the study. Eight DAs were selected from each region of Ghana using the mixed sampling technique. For each region, systematic sampling was used to select the sample used in the survey. To select the sample, a sampling fraction was calculated for each region by dividing the sampling frame by the sample size to give a value which is rounded to the next whole number $n$. The first sample was randomly chosen within the first $\mathrm{n}$ samples in the sampling frame after which every $n^{\text {th }}$ sample was chosen until the desired sample size was achieved. This sample was used for the study on the assumption that there exists a link between the 
characteristic of the sample and the population, allowing a series of referrals to be made within a circle of acquaintances (Berg, 1988).

A questionnaire survey involving closed-ended questions was considered suitable for this study. The questionnaire consisted of two sections. The first section involved the profile of the DAs. The second section assessed the benefits derived by clients from their project consultants. Caldwell and Hagan (1994) stated that ISO 9000-based QMS could improve the service quality of the firm, and hence the client's satisfaction, market share, revenue as well as workers' morale. ISO 9000QMS certification guarantees benefits to both client and consultants. Potential benefits expected to be derived by clients from their project consultants and also benefits of implementing ISO 9000QMS identified from relevant literature (Chan \& Tam, 2000; Tang \& Kam, 1999; Ahmed \& Kangari, 1995), were listed out for officials of the selected DAs to score their importance to the DAs. The officials were also asked to indicate how well their consultants have helped their DAs achieve the stated benefits on a five-point Likert scale (with 1 being the lowest and 5 being the highest level of benefit). Projects funded through the District Assemblies' Common Fund were chosen as the basis of the study because they provided a common platform with similar characteristic for all Assemblies. This therefore minimized the effects of other factors in the study. Out of the 80 questionnaires administered, 43responsive ones were received, giving a response rate of $53 \%$.

With the data analysis, the first part of the questionnaires involving the profile of the DAs was analyzed using percentages. The second part of the questionnaire was analyzed by comparing the mean values of the expected benefits and the actual benefits. The mean values were obtained by the following formula:

$$
\mu=\frac{\sum_{\mathrm{i}=1}^{5} i . \mathrm{f}_{\mathrm{i}}}{\sum_{\mathrm{i}=1}^{5} \mathrm{f}_{\mathrm{i}}}
$$

where, $f$ is the frequency of scoreifor the factor concerned. In this study, a mean value of 3.0 is considered as significant (Begum et al., 2006).

Client's satisfaction can be portrayed by comparing the mean values of the expected and actual benefits $(\mathrm{Ng}$, 2005). In order to adequately confirm whether there exists a significant difference between the means, one-way analysis of variance (ANOVA) was used to determine whether there was a disparity in the sample means of the expected and actual benefits.

\section{Findings and Discussion}

\subsection{Profile of Respondents}

District Assemblies in Ghana have been in existence for varying periods. Indeed, some DAs have been in existence longer than others. It was considered important to know the period of existence of DAs who took part in the study (Figure 1). This was used as an indicator of how long they have dealt with consultants.

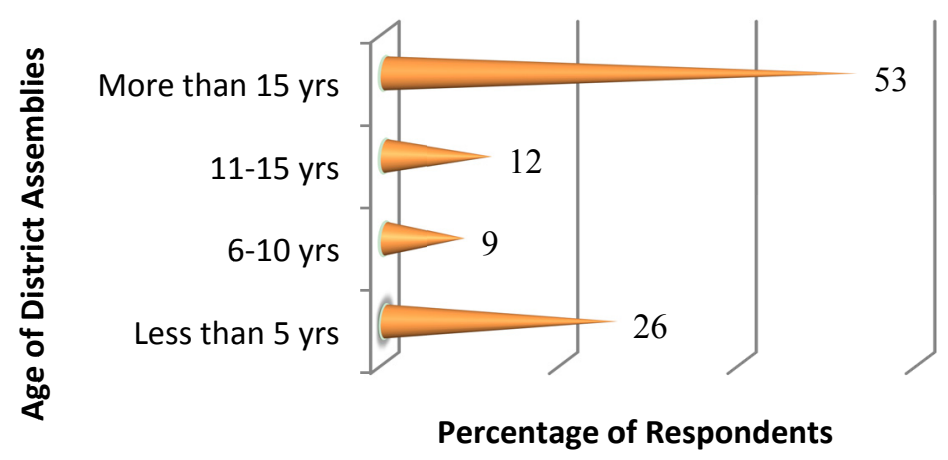

Figure 1. Period of existence of district assemblies

The results show that $26 \%$ of DAs in the study had existed for less than 5 years. However $74 \%$ of the DAs surveyed had existed for over five years. Thus majority of respondents have existed for over five years, a period long enough to give reliable information about the performance of consultants. 


\subsubsection{Designation of Respondents}

The questionnaires were completed by individuals working in the Assemblies on behalf of the DAs. It was considered necessary to know the designation of the respondents who actually completed the questionnaire because a wide array of staff work in the DAs, some of whom are better placed to provide accurate information on projects than others. Figure 2 shows the designation of individuals who completed the questionnaire.

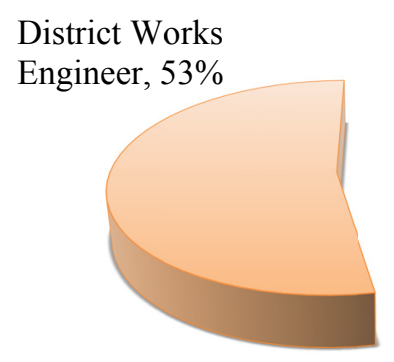

works supritendent

Figure. 2 Designation of respondents

From Figure 2, fifty three percent (53\%) and $47 \%$ of the questionnaires were completed by District Works Engineers and Works Superintendents respectively. Indeed, these are officials in the Districts directly involved in construction works and by extension those who work directly with consultants at the District Level. Respondents who completed the questionnaires were in good positions to provide reliable and accurate information on consultants' performance.

\subsubsection{Experience of Respondents}

In addition to the designation of the individual respondents, it was considered important to determine the length of time the respondents had been involved in project management. It is widely accepted that officials gain more experience in a field as their length of service increases. Table 1 gives the years of experience of the individual respondents.

Table 1. Experience of respondents

\begin{tabular}{ccc}
\hline Respondents years of experience & No of respondents & \% of respondents \\
\hline Less than 5 years & 6 & 14 \\
6 -10 years & 6 & 14 \\
11-15 years & 22 & 51 \\
More than 15 years & 9 & 21 \\
Total & 43 & 100 \\
\hline
\end{tabular}

Over $75 \%$ of the respondents have over five years working experience in Construction Management at the District level, hence are very likely to have the knowledge, skills and judgment to be able to differentiate between expected and actual benefits from the DAs project consultants.

\subsubsection{Engagement of Consultants by District Assemblies}

The use of consultants by DAs on their projects is done for a myriad of reasons. Figure 3 shows the reasons for engagement of consultants. DAs surveyed were of the view that consultants were engaged mainly because DAs did not have the required expertise for supervision of projects. Other significant reasons were heavy work load and the high cost and complexity of certain projects. Indeed, this is significant because some of the DAs that took part in the study did not have the capacity to carry out supervision of all construction works within their Districts which span over large geographical areas. 


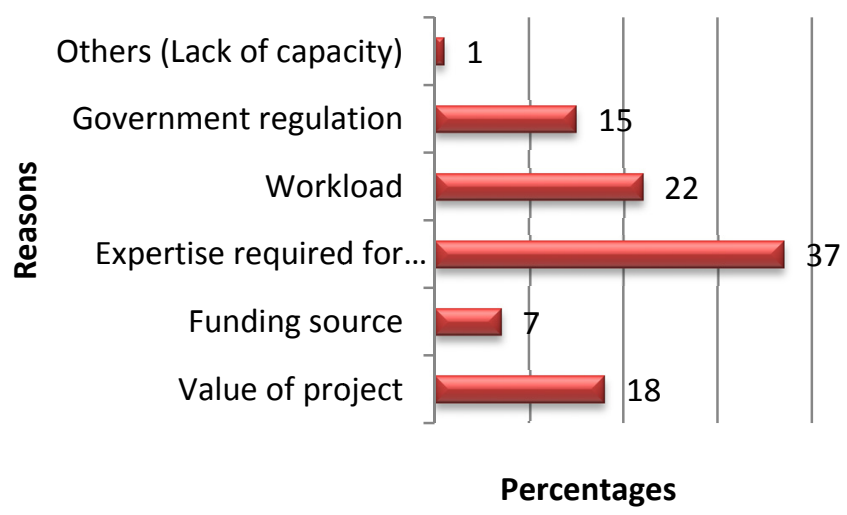

Figure 3. Reasons for engagement of consultants

\subsection{Benefits Derived by District Assemblies from Consultants}

The study assessed the respondents' views on the benefits derived by DAs from their project consultants. A summary of mean scores of expected and actual benefits from DAs' consultants is presented in Table 2. Mean scores of all the potential benefits evaluated are greater than 3.0, indicating that they are all important to the DAs. The most important benefits derived by DAs include increasing accuracy of project budget estimation, saving cost, minimizing risk through improved tender documents, promoting better communication with clients, and meeting client's deadline (Table 2).The first four actual benefits achieved by DAs from their project consultants were ranked as increasing reliability of project program, reduced time for responding to queries and complaints, saving cost, and meeting client's deadline (Table 2).

Table 2. Summary of mean scores of expected and actual benefits of ISO 9000 QMS implementation

\begin{tabular}{|c|c|c|c|c|c|c|c|}
\hline Code & Benefits & $\begin{array}{c}\text { Mean } \\
\text { expected } \\
\text { score }\end{array}$ & $\begin{array}{l}\text { Standard } \\
\text { Deviation }\end{array}$ & Rank & $\begin{array}{l}\text { Mean } \\
\text { actual } \\
\text { Score }\end{array}$ & $\begin{array}{l}\text { Standard } \\
\text { Deviation }\end{array}$ & Rank \\
\hline B1 & $\begin{array}{l}\text { Enhancing organization's } \\
\text { quality image }\end{array}$ & 3.86 & 1.02 & $10^{\text {th }}$ & 2.67 & 1.62 & $12^{\text {th }}$ \\
\hline B2 & $\begin{array}{l}\text { Improving quality of } \\
\text { engineering design }\end{array}$ & 3.70 & 1.03 & $11^{\text {th }}$ & 3.19 & 1.04 & $5^{\text {th }}$ \\
\hline B3 & $\begin{array}{l}\text { Improving quality of } \\
\text { engineering study } \\
\text { recommendation }\end{array}$ & 3.44 & 1.08 & $12^{\text {th }}$ & 2.84 & 1.29 & $11^{\text {th }}$ \\
\hline B4 & $\begin{array}{l}\text { Promoting better } \\
\text { communication with client }\end{array}$ & 4.16 & 0.79 & $4^{\text {th }}$ & 3.00 & 1.24 & $9^{\text {th }}$ \\
\hline B5 & Saving cost & 4.40 & 0.66 & $2^{\text {nd }}$ & 3.37 & 0.91 & $3^{\text {rd }}$ \\
\hline B6 & $\begin{array}{l}\text { Increasing accuracy of } \\
\text { project budget estimation }\end{array}$ & 4.60 & 0.46 & $1^{\text {st }}$ & 2.98 & 1.26 & $10^{\text {th }}$ \\
\hline B7 & $\begin{array}{l}\text { Increasing reliability of } \\
\text { project program }\end{array}$ & 4.10 & 0.81 & $6^{\text {th }}$ & 3.49 & 0.86 & $2^{\text {nd }}$ \\
\hline B8 & Meeting client's deadline & 4.13 & 0.80 & $5^{\text {th }}$ & 3.30 & 0.95 & $4^{\text {th }}$ \\
\hline B9 & $\begin{array}{l}\text { Reduced time for responding } \\
\text { to queries and complaints }\end{array}$ & 3.95 & 0.86 & $7^{\text {th }}$ & 3.60 & 0.68 & $1^{\text {st }}$ \\
\hline B10 & $\begin{array}{l}\text { Improve the management of } \\
\text { sub consultants }\end{array}$ & 3.93 & 0.95 & $8^{\text {th }}$ & 3.02 & 1.22 & $8^{\text {th }}$ \\
\hline B11 & $\begin{array}{l}\text { Minimizing risk through } \\
\text { improved tender documents }\end{array}$ & 4.19 & 0.68 & $3^{\text {rd }}$ & 3.14 & 1.13 & $6^{\text {th }}$ \\
\hline B12 & $\begin{array}{l}\text { Achieve continuous } \\
\text { improvements }\end{array}$ & 3.91 & 1.01 & $9^{\text {th }}$ & 3.14 & 1.15 & $7^{\text {th }}$ \\
\hline
\end{tabular}


The results presented in Table 2 and the graphical illustration of mean scores of the expected and actual benefits (Figure 4) show that means scores of the expected benefits are higher than those of the actual benefits for all the benefits evaluated. Thus, the benefits derived from consultants are lower than the DAs' expectations.

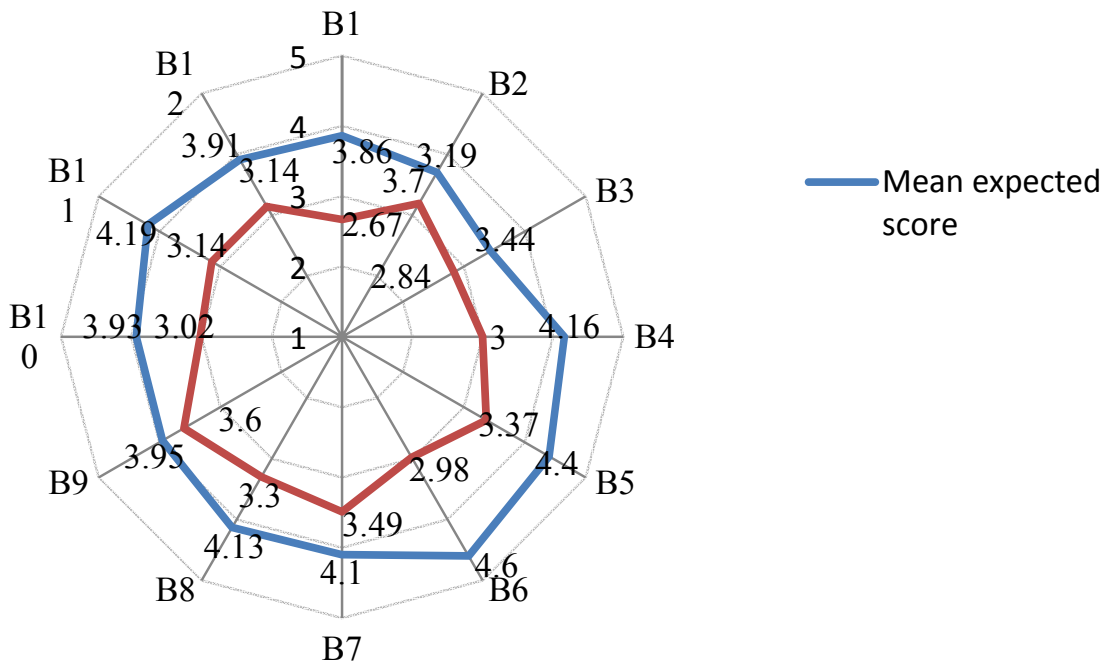

Figure 4. Comparison of mean scores of expected and actual benefits

\subsection{Analysis of Variances}

The one-way ANOVA was used to test whether there were statistically significant differences between the expected benefits and actual benefits. The results of the analysis are presented in the ANOVA table (Table 3).

Table 3. Analysis of variance for differences between the expected and actual benefits

\begin{tabular}{lccccccc}
\hline Benefit of ISO 9000 QMS implementation & $\boldsymbol{S S}$ & $\boldsymbol{d} \boldsymbol{f}$ & $\boldsymbol{M S}$ & $\boldsymbol{F}$ & $\boldsymbol{P}$-value & $\begin{array}{c}\boldsymbol{F} \\
\text { crit }\end{array}$ & Ranking \\
\hline Enhancing organizations quality image & 30.244 & 1 & 30.244 & 34.053 & $9.8 \mathrm{E}-08$ & 3.955 & 7 th \\
Improving quality of engineering design & 5.628 & 1 & 5.628 & 6.255 & 0.01433 & 3.955 & 2nd \\
Improving quality of engineering study & 7.860 & 1 & 7.860 & 6.706 & 0.01133 & 3.955 & 3rd \\
recommendation & & & & & & & \\
Promoting better communication with client & 29.070 & 1 & 29.070 & 48.974 & $5.9 \mathrm{E}-10$ & 3.955 & 11 th \\
Saving cost & 22.512 & 1 & 22.512 & 34.808 & $7.4 \mathrm{E}-08$ & 3.955 & 8 th \\
Increasing accuracy of project budget & 56.977 & 1 & 56.977 & 121.919 & $4.9 \mathrm{E}-18$ & 3.955 & 12 th \\
estimation & & & & & & & \\
Increasing reliability of project program & 14.244 & 1 & 14.244 & 24.020 & $4.6 \mathrm{E}-06$ & 3.955 & 6 th \\
Meeting client's deadline & 22.512 & 1 & 22.512 & 44.481 & $2.6 \mathrm{E}-09$ & 3.955 & 9 th \\
$\begin{array}{l}\text { Reduced time for responding to queries and } \\
\text { complaints }\end{array}$ & 2.616 & 1 & 2.616 & 4.211 & 0.04327 & 3.955 & 1 st \\
$\begin{array}{l}\text { Improve the management of sub consultants } \\
\text { Minimizing risk through improved tender }\end{array}$ & 17.686 & 1 & 17.686 & 18.624 & $4.3 \mathrm{E}-05$ & 3.955 & 4 th \\
documents & 23.547 & 1 & 23.547 & 47.461 & $9.6 \mathrm{E}-10$ & 3.955 & 10 th \\
Achieve continuous improvements & & & & & & & \\
\hline
\end{tabular}

Statistical difference between two sets of data can be determined by comparing the P-values generated from the analysis of the variances. At 5\%, p-values less than 0.05 imply a difference in the data and p-values greater than 0.05 imply no difference. From Table 3 , all the p-values are less than 0.05 indicating that there are significant differences between all the data sets. The expected benefits are statistically different from the actual benefits for each benefit evaluated.

By referring to the F-ratios, the benefits that exhibited the greatest difference or similarity can be identified. A large F-ratio implies a large difference whiles a small F-ratio implies a small difference. Very large F-ratios, 
indicating very large differences, were recorded for the following benefits: increasing accuracy of project budget estimation, minimizing risk through improved tender documents, promoting better communication with client, and meeting client's deadline.

The largest $\mathrm{F}$ ratio of 121 was in the benefit "increasing accuracy of project budget estimation" meaning it was the benefits that had the widest gap between the actual and expected benefits. This may be so because of the very high budgets overruns incurred by the DAs. Consultants do not help DAs much in executing their projects within budget. Thus consultants have to improve on their project budget estimation. Other benefits like "meeting client's deadline", "minimizing risk through improved tender documents" and "promoting better communication with client" had high F-ratios of 44.46, 47.46 and 48.974respectively, also suggesting that consultants need to take a critical look at issues with meeting deadlines, minimizing risks on behalf of DAs and improving communication with the DAs. The benefits with the least F-ratios were "reduced time for responding to queries and complaints" and "improved quality of their designs" with ratios of 4.21 and 6.25 respectively. These were the only benefits where the expectations were close to the actual benefits.

\section{Conclusion}

The results of the study show that of the potential benefits from DAs consultants, increasing accuracy of project budget estimation, saving cost, minimizing risk through improved tender documents, promoting better communication with clients, and meeting clients' deadline were considered important by the Das.

At $5 \%$ level of significance, there were significant differences between the expected benefits and the actual benefits the DAs derived from their consultants. For consultants to meet their clients expectation and clients also achieve enhanced benefits from their consultants, it is recommended that DAs include consultant's evaluation in their contracts with their consultants. District Assemblies should also evaluate their consultants on all projects to provide much needed feedback for the consultants to be able to examine their deficiencies for continual improvement and guaranteed benefits to the DAs. Consultants are recommended to seek regular feedbacks from the DAs and review their service quality on those deficient aspects.

\section{References}

Ahmed, S. M., \& Kangari, R. (1995). Analysis of client satisfaction factors in construction industry. Journal of Management in Engineering, 11(2), 36-44. http://dx.doi.org/10.1061/(ASCE)0742-597X(1995)11:2(36)

Banful, A. B. (2009). Do Institutions limit Clientelism? A study of the District Assemblies Common Fund in Ghana. International Food Policy Research Institute. Retrieved from http://www.ifpri.org/sites/default/files/publications/ifpridp00855.pdf

Barber, P., Graves, A., Hall, M., Sheath, D., \& Tomkins, C. (2000). Quality failure costs in civil engineeringprojects. International Journal of Quality \& Reliability Management, 17(4/5), 479-492. http://dx.doi.org/10.1108/02656710010298544

Bartlett J., Kotrlik, J., \& Higgings, C. (2001). Organisation Research, Determining appropriate sample size in survey Research. Information Technology Learning and Performance Journal, 19, 43-49. Retrieved from http://www.citeulike.org/user/Philonski/article/8878157

Begum, R. A., Siwar, C., Pereira, J. J., \& Jaafar, A. H. (2006). Implementation of waste management and minimization in the Malaysian construction industry. Conservation and Recycling, 51, 190-202. http://dx.doi.org/10.1016/j.bbr.2011.03.031.

Berg, S. (1988). Snowball sampling. In S. Kotz, \& N. L. Johnson (Eds.), Encyclopaedia of Statistical Sciences (Vol. 8, pp. 529-532).

Bingham, E. (1992). It takes two to tango. Management Consultancy (p. 26).

Botchway, E. (2000). The assessment of the role of and impact of Human resource base of the District Assemblies for effective utilisation of the District Assemblies common fund. Un-published MSC thesis. KNUST, Ghana.

Caldwell, J. A., \& Hagen, T. D. (1994). Engineering consultants implement TQM. Quality Progress, 27(1), 57-63. Retrieved from http:// www.robertsongeo.com/index.php?page=page\&id=28

Casadesus, M., Viadiu, M. F., \& Saizarbitoria, I. H. (2002). Quality service of ISO 9000 consultants. International Journal of Quality and Reliability Management, 19(8/9), 998-1013. http://dx.doi.org/10.1108/02656710210438096 
Chan, A. P. C., \& Tam, C. M. (2000). Factors affecting the quality of building projects in Hong Kong. InternationalJournal of Quality and Reliability Management, 17(4/5), 423-451. http://dx.doi.org/10.1108/02656710010298445.

Chini, A. R., \& Valdez, H. E. (2003). ISO 9000 and the US construction industry. Journal of Management in Engineering, 9(2), 69-77. http://dx.doi.org/10.1061/(ASCE)0742-597X(2003)19:2(69)

Chow Lai Kit, S. \& Ng, T. (2007). A fuzzy gap analysis model for evaluating the performance of engineering consultants. Automation in construction, 16, 425-435. http://dx.doi.org/10.1016/j.autcon.2006.07.010

Covin, T. J., \& Fisher, T. V. (1991). Consultant and client must work together. Journal of Management Consulting, 6(4), 11-20.

District Assemblies Act. (1993). Act 462 of Parliament of Ghana.

District Assemblies Common Fund Act. (1993). Act 455 of Parliament of Ghana.

Federation Internationale Des Ingenieurs Conseils (FIDIC). (1997). Quality-based selection for the procurement of consulting services. Lausanne, Switzerland.

Flood, R. L. (1993). Beyond TQM. John Wiley \& Sons, Chichester.

Goetsch, D. L., \& Davis, S. B. (2002). Understanding and Implementing ISO 9000: 2000 (2nd ed.). Prentice-Hall, Upper Saddle River, NJ.

Hamilton, E. E. (1988). The facilitation of organizational change: an empirical study of factors predicting change agents' effectiveness. The Journal of Applied Behavioral Science, 24(1), 37-59.

Hattan, D. E., \& Lalani, N. (1997). Selecting the right consultant team. Institute of Transportation Engineering Journal, 67(9), 40-46. Retrieved from http://trid.trb.org/view.aspx?id=1203689

Havemann, G. (2007). The challenge of engaging South Africa's unemployed in construction sector delivery'. Proceeding of the CIB World Building Conference on Construction for Development. Cape Town, South Africa. Heinemann, Oxford.

Hill, N., Self, B., \& Roche, G. (2002).Customer Satisfaction Measurement for ISO 9000:2000. Butterworth

Kasma, D. R. (1987). Consultant selection.Journal of Management in Engineering. ASCE, 3(4), 288-296. http://dx.doi.org/10.1061/(ASCE)9742-597X(1987)3:4(288)

Love, P. E. D., Gunasekaran, A., \& Li, H. (1998).Improving the competitiveness of manufacturing companies through continuous incremental change. TQM Magazine, 10(3), 177-185. http://dx.doi.org/10.1108/09544789810214828

McLachlin, R. (2000). Service quality in consulting: what is engagement success?. Managing Service Quality, 10(3), 141-150. http://dx.doi.org/10.1108/09604520010336669

Murphy, R. J. (2002). Implementing an ISO 9000: 2000 Based Quality Management System: Including Safety and Environmental Considerations. ABS Consulting Press, Rockville, MD.

Ng, S. T. (2005). Performance of engineering consultants in ISO 9000-based quality management systemsimplementation Engineering. Construction and Architectural Management. 12(6), 519-532. http://dx.doi.org/10.1108/09699980510634119

Osei-Asibey, D. (2005). Implementation of total quality management for District Assemblies Common fund projects at the Atwima District Assembly-pre contract stage. Unpublished MSc thesis, KNUST.

Public Procurement Board-Ghana. (2003). Manuals-Public Procurement Act of Ghana, Act 663 (2003). Retrieved from http://www.ppbghana.org/documents/FINAL MANUAL_PPB.pdf.

Rynning, M. (1992). Successful consulting with small and medium-sized versus large clients: meeting the needs of the client?. International Small Business Journal, 11(1), 47-60.

Samson, D., \& Parker, R. (1994). Service Quality: The Gap in the Australian Consulting Engineering Industry. International Journal of Quality \& Reliability Management, 11(7), 60-76. http://dx.doi.org/10.1108/02656719410738993

Smith, M. E. (2002). What client employees say about consultants. Leadership \& Organization Development Journal, 23(2), 1-15. 
Tan, R. R., \& Lu, Y. G. (1995). On the quality of construction engineering design projects: criteria and impacting factors. International Journal of Quality \& Reliability Management, 12(5), 353-364. http://dx.doi.org/10.1108/02656719510089975

Tang, S. L., \& Kam, C. W. (1999). A survey of ISO 9001 implementation in engineering consultancies in Hong Kong. International Journal of Quality and Reliability Management, 16(6), 562-574. http://dx.doi.org/10.1108/02656719910249810

World Bank Report. (2004). Presentation on the Tracking of Ghana's District Assemblies Common Fund Video Conference. April 14, 2004.

\section{Copyrights}

Copyright for this articleis retained by the author(s), with first publication rights granted to the journal.

This is an open-access article distributed under the terms and conditions of the CreativeCommons Attribution license (http://creativecommons.org/licenses/by/3.0/). 